\title{
Metodologia badań onomastycznych, red. Maria Biolik, Olsztyn 2003, ss. 656
}

Książka Metodologia badań onomastycznych zawiera 62 artykuły naukowe. Są to referaty wygłoszone podczas XIII Ogólnopolskiej Konferencji Onomastycznej z udziałem gości zagranicznych. Konferencja została zorganizowana przez Instytut Filologii Polskiej Uniwersytetu Warmińsko-Mazurskiego w Olsztynie i Komitet Językoznawstwa PAN i odbyła się we wrześniu 2002 r.

We Wstępie redaktor M. Biolik przedstawiła strukturę tomu oraz zawartość tematyczną sygnalizując wszystkie zamieszczone w tej publikacji artykuły. Dotyczą one ogólnych zagadnień onomastycznych oraz problemów szczegółowych z zakresu podstawowych subdyscyplin onomastycznych. W związku z tym trafnie wyodrębniono następujące części: Ogólne zagadnienia metodologiczne onomastyki (15 artykułów), Metody badawcze antroponimii (13), Problemy metodologiczne toponimii (16), Onomastyka literacka (8), Chrematonimia (10).

Najbardziej adekwatna treściowo w stosunku do ogólnie sformułowanego tytułu omawianej publikacji jest część pierwsza „Ogólne założenia metodologiczne onomastyki". Tę część otwiera artykuł R. Mrózka, w którym Autor porusza kilka istotnych kwestii teoretycznych, m.in. motywacje i konteksty społeczno-kulturowe procesów nominacyjnych, wytwory tych procesów, podział nazw według przyjętych kryteriów kategorialnych, własciwości strukturalno-gramatyczne i frekwencyjne nazw reprezentujących poszczególne grupy nazewnicze, aparat pojęciowo-terminologiczny itd. Badaczy onomastów szczególnie powinien zainteresować fragment tekstu, w którym jego Autor ujawnia trudności w konsekwentnym precyzyjnym, odpowiadającym istocie opisywanych zjawisk, stosowaniu określonych terminów (s. 14). Jak pisze R. Mrózek „Trudności te ujawniają się już nierzadko na poziomie elementarnego rozróżniania tego, co jest onomastyczne, czyli związane $z$ onomastyką jako dyscypliną badawczą, a co jest onimiczne, czyli związane z onimią...”. Ważny końcowy postulat głosi, że zadaniem powszednim i badawczą koniecznością jest uściślanie obszaru metodologicznoterminologicznego respektując przy tym podstawowe uzgodnienia terminologiczne w obrębie poszczególnych języków słowiańskich”. 
Onomastyczne szkoły badawcze, metody badawcze i klasyfikacje nazw miejscowych stosowane na obszarze całej słowiańszczyzny omawia E. RzetelskaFeleszko w artykule Metody opisu nazw miejscowych (ojkonimii) w krajach stowiańskich. Wskazuje podobieństwa i różnice w metodologii badawczej podając konkretne przykłady z toponimii słowiańskiej.

Artykuły R. Šramka i M. Harvalika zostały poświęcone słowiańskiej terminologii onomastycznej. Warto zainteresować się zaproponowaną przez R. Šramka systematyzacją dyscyplin i subdyscyplin onomastycznych, również w powiązaniu $\mathrm{z}$ innymi dyscyplinami badawczymi, np. historią, socjologią, etnografią, stylistyką, prawem i innymi.

Artykuł A. Cieślikowej stanowi krytyczne studium współczesnych słowotwórczych analiz onomastycznych. Badaczka wskazuje najczęściej popełniane błędy przytaczając na potwierdzenie konkretny materiał egzemplifikacyjny.

Z kolei S. Gala zwraca uwagę na elementy wspólne i odrębne w słowotwórstwie onomastycznym i słowotwórstwie gwarowym w kontekście ogólnych zasad derywacji w polszczyźnie ogólnej.

Problemom badawczym i metodologicznym onomastyki regionalnej poświęcone są artykuły L. Dacewicz (Podlasie) i M. Biolik (Warmia i Mazury).

W części pierwszej znalazły się też prace dotyczące funkcjonowania nazw własnych w określonych wspólnotach komunikatywnych (J. Krsko) i społecznych (P. Odaloš), praca omawiająca rolę czynników kulturowo-historycznych w badaniu etymologii nazw własnych (W. Łuczyk). Zjawisko występowania nazw własnych w funkcji nieonomastycznej sygnalizuje E. Pałuszyńska, a problem apelatywizacji imion w leksyce socjolektalnej prezentuje J. Obara.

Część I zamyka artykuł C. Atzenbecka omawiający zastosowanie w badaniach onomastycznych programu komputerowego Thorn.

Problemy badawcze antroponimii są przedmiotem uwagi 13 kolejnych artykułów. Proces kształtowania się nazwisk w kontekście socjologicznym i kulturowym na określonych obszarach omawiają: Z. Abramowicz w Brańsku na Podlasiu (XVII w.), H. Popowska-Taborska - na terenach dolno- i górnołużyckich, W. Szulowska - na Mazowszu (XVI w.), B.A. Sieradzcy - we Wrześni (XVIII w.) i E. Rudolf-Ziółkowska - na kresach południowo-wschodnich.

Kilka artykułów poświęcono odrębnym typom nazwisk: E. Breza omawia nazwiska równe nazwom miejscowości, E. Raszewska-Żurek - nazwiska równe imionom, E. Rudnicka-Fira - nazwiska utworzone od nazw zawodów i godności, a D. Lech - nazwiska odapelatywne używane na Sląsku Opolskim. Wyrazy pospolite w podstawach nazwisk analizuje $\mathrm{H}$. Górny wykorzystując w tym celu metodę pól semantycznych. Zasady redakcji i wykorzystania 10-tomowego słownika nazwisk używanych w Polsce na pocz. XXI w. prezentuje jego autor K. Rymut. 
Dwie ostatnie prace $\mathrm{z}$ zakresu antroponimii dotyczą imion. Imiennictwo żeńskich zgromadzeń zakonnych przedstawia S. Sochacka, a imiona używane przez mieszkańców Stargardu Szczecińskiego w l. 1945-2000 S. Stramek.

Duża różnorodność tematyczna cechuje kolejną część poświęconą problemom i metodom badawczym w szeroko pojętej toponimii. Kilka prac ukazuje funkcjonowanie różnych nazw geograficznych, odnoszących się do tego samego obiektu na różnych terytoriach (Polska, Bułgaria, Austria): Cz. Kosyla, L. Dmitrowej-Todorowej, F. Frhr. Lochner von Huttenbacha, J. Ignatowicz-Skowrońskiej i H. Gaczyńskiej. Do tej tematyki nawiązuje także artykuł S.A. Nikitina prezentujący toponimy rosyjskie zastąpione w l. 1918-1930 innymi nazwami. Nazwy ulic i traktów komunikacyjnych na podstawie pojęcia prototypu klasyfikuje A. Myszka. Wpływ nieregularnego rozwoju fonetycznego spowodowanego frekwencją na toponimy chorwackie typu Supetar w Dalmacji ukazuje W. Mańczak.

Budowa toponimów jest przedmiotem uwagi kolejnych 4 prac. L. OliwowaNezbedowa omawia mikrotoponimy z przyimkiem i bez przyimka, a I. Różycka mikrotoponimy złożone z podstawą werbalną. E. Foster wskazuje podstawy derywacyjne nazw miejscowych $\mathrm{z}$ sufiksami -ov-, -in- w Meklenburgii i Bradenburgii, a D. Kopertowska zachowane cechy gwarowe w toponimii regionu świętokrzyskiego.

Ponadto w części tzw. toponimicznej znajdziemy ciekawą pracę J. Dumy poświęconą nazwom polskich rzek z przymiotnikowym określeniem barwy wody biały - czarny. K. i Z. Zierhofferowie prezentują choronimy w formie zestawień, a I. Bily mapy zamieszczone w Atlasie starołużyckich nazw miejscowych. Kilka nieznanych etymologii nazw miejscowych z terenu Warszawy przytacza E. Czerniakowska.

Kolejne artykuły tworzą grupę tematyczną z zakresu onomastyki literackiej. Tę część otwiera praca I. Sarnowskiej-Giefing „Onomastyka literacka - integracja językoznawstwa i literaturoznawstwa?”. Jej Autorka dokonuje przeglądu metod i trendów panujących w polskiej i światowej metodologii badań nazw własnych w tekście literackim, określa perspektywy badawcze onomastyki literackiej sugerując, że badanie nazewnictwa w literaturze, mając charakter opisowo-interpretacyjny w naturalny sposób zbliża się do interpretująco-wartościujących analiz literaturoznawczych. Dwa kolejne artykuły ukazują nazwy własne we frazeologii w oparciu o Nowa księge przystów $i$ wyrażeń przystowiowych $i$ innych zbiorów paremiologicznych (A. Nowakowska i L. Tomczak). Funkcje stylistyczne nazw własnych w tekście literackim omawia A. Raszewska-Klimas, a funkcję dydaktycznowychowawczą nazw własnych w literaturze dziecięcej prezentuje M. Czaplicka. Z kolei K. Kuffner-Obrzut omawia nazwy osobowe w utworach Małgorzaty Musirowicz, I. Domaciuk - antroponimy i toponimy w powieściach Anny Brzezińskiej, a hydronimy w utworach Juliusza Słowackiego - U. Kęsikowa. 
Książkę zamykają teksty poświęcone zagadnieniom mieszczącym się w zakresie chrematonimii. Wyraźnie wzrastająca dynamika rozwoju tej stosunkowo młodej gałęzi onomastyki stoi w ścisłym związku $\mathrm{z}$ wysokim tempem zmian zachodzących w rzeczywistości pozajęzykowej. Coraz liczniejsze nazwy obiektów związanych z nowoczesną cywilizacją i nazwy środków konsumpcji stały się interesujące ze względu na proces nominacji uwarunkowany sytuacją socjolingwistyczną i kulturową. Obszerny artykuł A. Superanskiej prezentuje historię wprowadzania znaków towarowych w Rosji poczynając od końca XIX w. (początki tego procesu) do czasów współczesnych. W opisie uwzględniono kontekst historyczno-kulturowy, nie bez znaczenia był też aspekt psychologiczny, społeczny i inne. Kolejny, równie interesujący artykuł autorstwa A. Siwca dotyczy nazw obiektów handlowych w Polsce i ich uwarunkowań społeczno-komunikacyjnch (motywacja, funkcjonowanie, obieg i odbiór społeczny, rola reklamy w tworzeniu i rozpowszechnianiu nazw handlowych, wpływy obce).

Kilka kolejnych prac uwzględnia: nazwy macedońskich barów i restauracji (W. Miowska, M. Momirowska), nazwy łódzkich postojów taksówek (S. Tomaszewska), nazewnictwo poznańskich młynów wodnych (M. Rutkiewicz), nazewnictwo instytucji astronomicznych, obserwatoriów itd. (E. Jakus-Borkowa). Spektrum zagadnień szeroko rozumianej chrematonimii obejmuje również nazwy polskich filmów (K. Skowronek, B. Skowronek), nazwy własne klejnotów (K. Węgorowska), nazwy własne w internecie, tzw. e-nimy (M. Graf) oraz nazwy własne w przestrzeni wirtualnej (R. Łobodzińska).

$\mathrm{Na}$ ogół w pracach zbiorowych stosuje się jednolity sposób prezentacji wykorzystanej literatury przedmiotu. W omawianej publikacji zachowano autorskie propozycje, które sprowadają się do dwóch sposobów: przypisów u dołu strony lub poprzez podawanie $\mathrm{w}$ tekście $\mathrm{w}$ nawiasach nazwiska autora i roku wydania publikacji a spisu całej literatury na końcu artykułu. Ta niejednolitość nie stanowi mankamentu. Taki stan rzeczy można potraktować jak jedno z możliwych rozwiązań redakcyjnych. Ujednolicenie zapisu bibliograficznego w tak opasłym tomie wymagałoby nieadekwatnie dużego w stosunku do oczekiwanych rezultatów nakładu pracy. Poza tym od strony redakcyjnej tom odznacza się starannością i dbałością o szczegóły.

$\mathrm{Na}$ zakończenie trzeba zauważyć, że niektóre prace szczegółowe z zakresu antroponimii, czy też toponimii, niezupełnie mieszczą się w dość ogólnej formule tematycznej recenzowanego tomu. Jest to naturalna kolej rzeczy, jeśli zwycięża koncepcja zamieszczenia w tomie pokonferencyjnym wszystkich referatów. Niemniej jednak omawianą publikację cechuje ogromne bogactwo problematyki badawczej z zakresu onomastyki. W tomie znajdziemy zarówno prace omawiające tradycyjne metody badań jak i prace prezentujące nowe i nowoczesne ( $\mathrm{z}$ użyciem programu komputerowego) techniki i metody badawcze. W poszczególnych ar- 
tykułach omawiane są typy nazw własnych mocno zakorzenione w tradycji badawczej (antroponimy i toponimy), jak i nazewnictwo odnoszone do stosunkowo młodej dyscypliny badawczej-chrematonimii.

Warto zajrzeć do tego tomu. Każdy badacz onomasta znajdzie w nim coś dla siebie - nowego, interesującego, inspirującego.

Leonarda Dacewicz 